\title{
Partisipasi Masyarakat Lokal di Desa Karangan Hilir dalam Pelestarian Kebun dan Hutan Pendidikan STIPER Kutai Timur
}

\author{
Jerlita Kadang Allo ${ }^{1}$ dan Mufti Perwira Putra ${ }^{2}$ \\ ${ }^{1}$ Sekolah Tinggi Pertanian Kutai Timur, Soekarno Hatta, Sangatta, Kutai Timur, \\ Kalimantan Timur \\ ${ }^{1}$ Email: kadangallojerlita@gmail.com
}

\begin{abstract}
The participation of local communities in the management of forest resources will increase their responsibility and concern for the environment of the forest area. In this case, the community is not seen as an object that needs to be fostered, but also a party that can be invited to work together for sustainable protection of an area. Or in other words also as "The activist of forest conservation". Therefore the role of local communities is needed both in the planning, implementation, monitoring and evaluation stages. The purpose of this research is to identify the function of participation and the intensity of participation of local community elements in maintaining and preserving STIPER Kutai Timur's Farm and Forest Education Centre. The benefits of this research are as a reference material for STIPER Kutai Timur's in making policies in the STIPER Kutai Timur's Farm and Forest Education Centre management program and for the community; as a source of information that can give birth to public awareness of the importance of participating in the Education and Conservation program at STIPER Kutai Timur. This research was conducted in Karangan Hilir Village by selecting several respondents through a stratified sampling consisting of youth, women, patriach, farmer groups, community leaders and stakeholders related to their interests in the STIPER Kutai Timur's Farm and Forest Education Centre. The processing and analysis of data uses the empowerment index. From the results of the study using the empowerment index, the numbers ranged from 1-25, which means that community participation around the STIPER Kutai Timur's Farm and Forest Education Centre is categorized as very inactive. This is due to the management of STIPER garden and forest education which are fully handled directly by STIPER Kutai Timur. Seeing the lack of participation of local communities, it is expected that in the future the management of STIPER Kutai Timur's Farm and Forest Education Centre will involve the participation of local communities so that the community's care and responsibilities contribute to preserving STIPER Kutai Timur's Farm and Forest Education Centre
\end{abstract}

Keywords: , Farms and Forests education, Function, Intensity, Participation, STIPER Kutai Timur

\begin{abstract}
ABSTRAK
Partisipasi masyarakat lokal dalam pengelolaan sumber daya hutan akan meningkatkan tanggung jawab dan kepedulian mereka terhadap lingkungan kawasan hutan. Dalam hal ini, masyarakat tidak dipandang sebagai objek yang perlu dibina, tetapi juga merupakan pihak yang dapat diajak bekerja sama untuk perlindungan yang lestari dari suatu kawasan. Atau dengan perkataan lain juga sebagai "pelaku pelestarian kawasan hutan". Karena itu diperlukan peran masyarakat lokal baik dalam tahap perencanaan, pelaksanaan, pemantauan, maupun evaluasi. Tujuan dari penelitian ini adalah untuk mengidentifikasi fungsi partisipasi dan intensitas partisipasi unsur masyarakat lokal dalam menjaga dan melestarikan Kebun dan Hutan Pendidikan STIPER Kutai Timur. Manfaat dari penelitian ini adalah sebagai bahan rujukan bagi STIPER Kutai Timur dalam pembuatan kebijakan dalam program pengelolaan Kebun dan Hutan Pendidikan STIPER dan bagi masyarakat; sebagai sumber informasi yang dapat melahirkan kesadaran masyarakat akan pentingnya berpartisipasi dalam program pelestarian Kebun dan Hutan Pendidikan STIPER Kutai Timur. Penelitian ini dilaksanakan di Desa Karangan Hilir dengan memilih beberapa responden secara stratified sampling yang terdiri dari pemuda, wanita, kepala keluarga, kelompok tani, tokoh masyarakat dan para stakeholder yang terkait kepentingannya dengan kebun dan hutan pendidikan STIPER. Pengolahan dan analisis data menggunakan empowerment
\end{abstract}


index. Dari hasil penelitian dengan menggunakan empowerment index menunjukkan angka yang berkisar antara 1-25 yang artinya bahwa partisipasi masyarakat sekitar kawasan kebun dan hutan pendidikan STIPER masuk dalam kategori sangat tidak aktif. Hal tersebut disebabkan pengelolaan kebun dan hutan pendidikan STIPER sepenuhnya ditangani langsung oleh STIPER. Melihat partisipasi masyarakat lokal yang masih sangat kurang maka diharapkan ke depan pengelolaan kebun dan hutan pendidikan STIPER dapat melibatkan peran serta masyarakat lokal sehingga kepedulian dan tanggungjawab masyarakat untuk turut melestarikan kebun dan hutan STIPER semakin meningkat.

Kata kunci: Fungsi, Intensitas, Partisipasi, Kebun dan Hutan Pendidikan, STIPER Kutai Timur

\section{Pendahuluan}

Indonesia yang terletak di daerah khatulistiwa mempunyai hutan hujan tropis yang luas dan lebat. Di samping itu, Indonesia juga memiliki kekayaan sumber daya alam dan keanekaragaman plasma nutfah yang sangat beragam, yang bermanfaat bagi hidup dan kehidupan tidak saja penting bagi Indonesia tetapi juga bagi dunia pada umumnya. Namun demikian, hutan di Indonesia tergolong hutan tropis yang sangat dikhawatirkan keberadaannya (eksistensinya) secara lestari. Ini dikarenakan adanya tekanan-tekanan yang semakin lama semakin bertambah berat, seperti adanya penebangan-penebangan tanpa perhitungan matang yang tentunya akan merusak kelestarian hutan (Arief, 1994).

Faktor utama kerusakan tersebut secara umum adalah antara lain berupa atau disebabkan oleh adanya gangguan manusia. Pada awalnya lebih dikenal sebagai eksploitasi kayu yang berlebihan, tetapi selanjutnya juga akibat dari perambahan kawasan untuk pemukiman dan kegiatan pertanian serta pembalakan liar. Brown and Pearce (1994) menyatakan bahwa, perubahan kawasan hutan ke non kawasan hutan (pelepasan kawasan hutan) terjadi sebagai akibat adanya persaingan dalam pemanfaatn sumber daya hutan antar pemangku kepentingan. Sebagai contoh konversi lahan hutan untuk pembangunan infrastruktur, pertanian, perkebunan, pertambangan, pemukiman, pembangunan perkotaan dan industri. Selanjutnya Purba dkk. (2014) menyatakan bahwa antara tahun 2008 hingga 2013 adalah masa subur aktivitas pertambangan di kawasan hutan. Dari yang semula hanya celah kecil berubah menjadi hamparan karpet merah bagi perusahaan tambang untuk masuk dan mengeksploitasi kawasan hutan.

Partisipasi dari seluruh unsur masyarakat lokal dalam program pembangunan akan memberikan pengalaman dan rasa memiliki yang pada tahap berikutnya akan dapat meningkatkan rasa tanggung jawab dan kemauan untuk mempertahankan hasil-hasil program secara dinamis (Mujahiddin dkk., 2006). Partisipasi adalah ketersediaan untuk membantu berhasilnya setiap program sesuai dengan kemampuan setiap orang tanpa mengorbankan kepentingan diri sendiri (Mubyarto, 1984). Selanjutnya Sembiring dkk. (1999) menyatakan definisi partisipasi bila dikaitkan dengan peranan masyarakat adalah bentuk keterlibatan masyarakat di dalam urusan pembangunan, baik secara perorangan 
maupun dalam bentuk kelembagaan dalam berbagai tahap perencanaan, pelaksanaan, pengawasan dan evaluasi. Kemudian Pranoto (2001), mendefinisikan masyarakat lokal sebagai istilah yang sering digunakan untuk masyarakat yang berada di dalam ataupun di sekitar hutan.

Partisipasi masyarakat lokal dalam pengelolaan sumber daya hutan akan meningkatkan tanggung jawab dan kepedulian mereka terhadap lingkungan kawasan hutan. Dalam hal ini, masyarakat tidak dipandang sebagai Objek yang perlu dibina, tetapi juga merupakan pihak yang dapat diajak bekerja sama untuk perlindungan yang lestari dari suatu kawasan. Atau dengan perkataan lain juga sebagai "pelaku pelestarian kawasan hutan". Karena itu diperlukan peran masyarakat lokal baik dalam tahap perencanaan, pelaksanaan, pemantauan, maupun evaluasi.

Tujuan dari pelaksanaan penelitian ini adalah mengidentifikasi fungsi partisipasi dan intensitas partisipasi unsur masyarakat lokal dalam menjaga dan melestarikan Kebun dan Hutan Pendidikan STIPER Kutai Timur.

Manfaat dari penelitian ini adalah sebagai bahan masukan/ rujukan bagi STIPER Kutai Timur dalam pembuatan kebijakan dalam program pengelolaan Kebun dan Hutan Pendidikan STIPER dan bagi masyarakat; sebagai acuan dan sumber informasi yang dapat melahirkan kesadaran masyarakat akan pentingnya mereka berpartisipasi dalam program pelestarian hutan khususnya di Kebun dan Hutan Pendidikan STIPER Kutai Timur.

\section{Metode Penelitian}

Penelitian dilaksanakan di desa Karangan Hilir Kecamatan Karangan Kabupaten Kutai Timur. Waktu pelaksanaan pengambilan data di lapangan dan pengolahan data mulai bulan Februari - Desember 2019. Bahan dan alat penelitian yang digunakan dalam penelitian ini adalah kuesioner, peta-peta serta dokumen-dokumen berbagai laporan lainnya yang berkaitan dengan Kebun dan Hutan Pendidikan STIPER Kutai Timur, kamera dan tape recorder, digunakan untuk merekam informasi saat dilakukan wawancara sehingga dapat dipastikan tidak ada informasi responden yang hilang.

Objek utama/ responden dalam penelitian ini adalah kelompok masyarakat yang tinggal di sekitar dan kehidupannya memiliki keterkaitan langsung dengan Kebun dan hutan pendidikan STIPER Kutai Timur, Kelompok Tani, Tokoh masyarakat dan pemerintah setempat Responden yang diambil ditentukan dengan cara stratified sampling yaitu penentuan sampel yang dilakukan dengan membagi populasi dalam beberapa strata sesuai dengan tuntutan rumusan pengolahan data yang digunakan dalam penelitian ini. Strata (kelompok) populasinya adalah a) pemimpin, b) kelompok minat, c) kepala keluarga, d) wanita dan e) pemuda, dengan jumlah responden setiap desa sebanyak 30 orang. Menurut Cohen, et.al, (2007) semakin besar sample dari besarnya populasi yang ada 
ISSN 2354-7251 (print)

adalah semakin baik, akan tetapi ada jumlah batas minimal yang harus diambil oleh peneliti yaitu sebanyak 30 sampel. Senada dengan pendapat tersebut, Roscoe dalam Sugiono (2012) menyarankan tentang ukuran sampel untuk penelitian bahwa ukuran sampel yang layak dalam penelitian adalah antara 30 sampai dengan 500. Selanjutnya Lestari (2004) juga menyatakan bahwa ukuran minimum sampel yang dapat diterima berdasarkan desain penelitian yang menggunakan metode deskriptif-korelasional, minimal adalah 30 subjek sedangkan pemilihan desa ditetapkan secara purposive sampling dengan kriteria desa yang berada terdekat lokasi Kebun dan Hutan Pendidikan STIPER Kutai Timur, untuk itu ditetapkan/dipilih Desa Karangan Hilir.

Hasil jawaban yang telah dikumpulkan dari responden kemudian dianalisis dengan menggunakan metode perkalian angka indeks pelaku (who), dengan angka indeks dalam hal apa (what) dan angka indeks bagaimana partisipasi (how), sesuai dengan Tabel 1.

Tabel 1. Participation-Empowerment Index

\begin{tabular}{l|l|l}
\hline \multicolumn{1}{c|}{ Extent (who) } & \multicolumn{1}{c|}{ Function (in what) } & \multicolumn{1}{c}{ Intensity (how) } \\
\hline 5. Youth & 5. Management & 5. Total control \\
\hline 4. Women & 4. Planning & 4. Initiation action \\
\hline 3. All households & 3. Implementation & 3. Decision making \\
\hline 2. Interest group & 2. Maintenance & 2. Consultation \\
\hline 1. Leader only & 1. Distribution / use & 1. Informing \\
\hline
\end{tabular}

Sumber: Sumantri (2000). Keterangan : angka 1, 2, 3, 4, 5 adalah indeks.

Berdasarkan perkalian tersebut diperoleh angka tertinggi 125 dan angka terendah 1. Kemudian untuk memberikan skala penilaian tingkat partisipasi masyarakat lokal dari nilai terendah sampai tertinggi dengan pembagian kelompok sebanyak 5 kelompok dengan kategori: (a) sangat tidak aktif, (b) tidak aktif, (c) cukup aktif, (d) aktif dan (e) sangat aktif, dilakukan dengan cara menurut Sudjana (1992), sebagai berikut:

1). Menentukan rentang nilai dengan rumus:

Rentang $(\mathrm{R})=$ Nilai Tertinggi - Nilai Terendah

2). Menentukan banyaknya kelompok, dalam hal ini banyaknya kelas ditentukan sebanyak 5 kelompok sesuai kategori penilaian tersebut di atas.

3). Menentukan panjang kelas dengan rumus:

$$
P=\frac{R}{K}
$$

Keterangan: $\quad \mathrm{P}=$ Panjang kelas

$$
\begin{aligned}
& \mathrm{R}=\text { Rentang } \\
& \mathrm{K}=\text { Banyaknya kelompok }
\end{aligned}
$$

Dari rumus-rumus di atas diperoleh nilai-nilai sebagai berikut:

$$
\begin{aligned}
& \mathrm{R}=125-1=124 \\
& \mathrm{~K}=5 \\
& \mathrm{P}=124: 5=24,8 \text { (dibulatkan menjadi 25) }
\end{aligned}
$$


Dengan demikian pengkategorian partisipasi masyarakat lokal dalam menjaga dan melestarikan Kebun dan Hutan Pendidikan STIPER Kutai Timur adalah sebagai berikut:

a) Partisipasi sangat tidak aktif, jika nilai indeksnya 1-25

b) Partisipasi tidak aktif, jika nilai indeksnya 26-50

c) Partisipasi cukup aktif, jika nilai indeksnya 51-75

d) Partsipasi aktif, jika nilai indeks 76-100

e) Partisipasi sangat aktif, jika nilai indeks 101-125

\section{Hasil dan Pembahasan \\ Pengelompokan Responden}

Dari hasil wawancara yang dilakukan terhadap masyarakat sekitar kawasan Kebun dan Hutan Pendidikan STIPER diketahui laki-laki sebanyak 22 orang sedangkan jumlah responden perempuan 8 orang. Sesuai dengan data tersebut maka responden terbanyak adalah laki-laki. Berdasarkan Hasil wawancara yang dilakukan dapat diketahui bahwa responden yang umurnya 20-40 tahun sebanyak 11 orang responden, umur 41-50 sebanyak 11 orang sedangkan yang umurnya 51-60 tahun sebanyak 8 orang responden. Dari hasil tersebut dapat dilihat responden yang paling banyak adalah responden dengan rentang usia 20-50 tahun. (73,33 \%). Menurut BKKBN (2014), penduduk usia produktif adalah penduduk yang masuk dalam rentang usia antara 15- 64 tahun. Penduduk usia itu dianggap sudah mampu menghasilkan barang maupun jasa dalam proses produksi, sehingga responden pada umumnya masih produktif untuk bekerja. Hal ini sangat sesuai dengan kondisi di lapangan bahwa responden pada umumnya masih produktif untuk bekerja, sehingga akan berpengaruh pada keikutsertaan dalam berperan aktif melestarikan Kebun dan Hutan Pendidikan STIPER.

Responden yang mempunyai latar belakang pendidikan SD berjumlah 18 orang tetapi pada umumnya sudah memiliki kemampuan baca tulis, SMP berjumlah 7 orang dan SMA berjumlah 5 orang Latar belakang pendidikan seseorang akan dapat mempengaruhi dalam kehidupannya di masyarakat. Di samping itu latar belakang pendidikan akan menjadi dasar berfikir dalam mengungkapkan pendapat dan dalam berpartisipasi secara aktif dalam pengelolaan Kebun dan Hutan Pendidikan STIPER.

Mata pencaharian responden dapat dikatagorikan atas dua kelompok, yaitu dari usahatani dan non usahatani. Mata pencaharian dari usahatani adalah hasil pertanian seperti perladangan dan perkebunan, sedangkan contoh non usahatani adalah pegawai negeri, berdagang, tukang kayu dan wiraswasta lainnya. Sumber pendapatan utama responden adalah dari usahatani. Responden pada umumnya berasal dari usahatani (80\%). Usaha di sektor pertanian pada umumnya juga dilakukan oleh responden yang 
memiliki mata pencaharian di sektor non pertanian, namun sifatnya hanya sekedar sampingan yang berfungsi sebagai tambahan penghasilan rumah tangga.

\section{Partisipasi Masyarakat Lokal dalam Pelestarian Kebun dan Hutan Pendidikan STIPER}

Perlindungan dan pengamanan kawasan adalah upaya melindungi/ mengamankan kawasan dari berbagai gangguan. Hal tersebut dilakukan melalui kegiatan-kegiatan perlindungan dan pengamanan batas fisik kawasan, identifikasi daerah-daerah rawan gangguan, sosialisasi tata batas (luar, fungsi, pengelolaan), pengembangan kemitraan dengan masyarakat, pemasangan tanda patok batas dan tanda-tanda larangan/ ajakan/ himbauan, penegakan hukum dan pembinaan masyarakat, pembuatan ilaran api, pemusnahan hama dan penyakit, dan lain sebagainya merupakan program yang ditujukan untuk menjaga eksistensi kawasan.

Setiap program pembangunan termasuk program pelestarian Kebun dan Hutan Pendidikan STIPER perlu adanya kebijakan pengelolaan terutama untuk mengakomodasi kepentingan masyarakat, khususnya pemukim di dalam/ sekitar kawasan, sehingga masyarakat harus dipandang sebagai bagian tak terpisahkan dari sistem pengelolaan kawasan. Menurut Poli Sutrisno (2004), masyarakat lokal adalah pihak yang paling dekat dengan masalah pembangunan berkelanjutan. Bahkan partisipasi mereka dalam pembangunan adalah merupakan sebuah kebutuhan dan pemanfaatan bagi terselenggarannya pembangunan berkelanjutan.

Menurut Margiono (1999), unsur-unsur masyarakat lokal adalah bagian dari keseluruhan sistem masyarakat lokal, sehingga hubungan antar unsur merupakan bagian yang tidak terpisahkan. Oleh karenanya program pelestarian berbasis partisipasi masyarakat lokal harus mampu menumbuhkan dukungan dan sikap kepedulian seluruh lapisan masyarakat, terhadap tujuan akhir dari program tersebut ditentukan oleh partisipasi masyarakat lokal itu sendiri.

Partisipasi masyarakat lokal dalam program pembangunan akan menumbuhkan pengalaman dan rasa memiliki yang pada tahap berikutnya akan dapat meningkatkan rasa tanggung jawab dan kemauan untuk mempertahankan hasil-hasil program secara dinamis (Margiono, 1999).

Hasil penelitian tentang keterlibatan masyarakat lokal di lokasi penelitian Desa Karangan Hilir pada fungsi partisipasi dalam pelestarian Kebun dan Hutan Pendidikan STIPER disajikan pada Tabel 2. Tabel 2 menunjukkan bahwa masyarakat lokal desa Karangan Hilir yang terlibat pada fungsi partisipasi "pendistribusian", "pemeliharaan", "pelaksanaan" dan "perencanaan" relatif agak bagus sebesar $56.67 \%$ (sebanyak 17 responden dari total 30 responden). Pada fungsi partisipasi "manajemen" tidak terdapat keterlibatan masyarakat, Pada tahap manajemen pada umumnya masyarakat tidak berpartisipasi, dengan alasan tidak dilibatkan. 
Tabel 2. Keterlibatan Masyarakat Lokal pada Fungsi Partisipasi dalamPelestarian Kebun dan Hutan Pendidikan STIPER

\begin{tabular}{c|l|c|c}
\hline \multirow{2}{*}{ No } & \multicolumn{1}{|c|}{ Keterlibatan Masyarakat } & \multicolumn{2}{c}{ Desa Karangan Hilir } \\
\cline { 3 - 4 } & \multicolumn{1}{|c}{$\mathbf{N}$} & $\%$ \\
\hline 1. & $\begin{array}{l}\text { Keikutsertaan pada penggunaan atau pendistribusian } \\
\text { (penanaman/ pemasangan) fasilitas fisik (tanaman, patok, } \\
\text { plang) }\end{array}$ & 7 & 23.33 \\
\hline 2. & $\begin{array}{l}\text { Keikutsertaan dalam mendukung keberhasilan pemeliharaan } \\
\text { (menjaga dan merawat) fasilitas fisik (tanaman, patok, plang); }\end{array}$ & 6 & 20.00 \\
\hline 3. & Keikutsertaan dalam bentuk; Pelaksanaan program & 2 & 6.67 \\
\hline 4. & Keikutsertaan dalam perencanaan program & 2 & 6.67 \\
\hline 5. & Keikutsertaan dalam Manajemen & - & - \\
\hline & Jumlah responden berpartisipasi & $\mathbf{1 7}$ & $\mathbf{5 6 . 6 7}$ \\
\hline & Jumlah responden tidak berpartisipasi & $\mathbf{1 3}$ & $\mathbf{4 3 . 3 3}$ \\
\hline & \multicolumn{1}{|c|}{ T o t a I } & $\mathbf{3 0}$ & $\mathbf{1 0 0 , 0 0}$ \\
\hline
\end{tabular}

Keterangan : $\mathrm{N}=$ jumlah responden

Pada Tabel 3 berikut, menunjukan masyarakat lokal yang terlibat pada intensitas partisipasi relatif lebih besar dari fungsi partisipasi yaitu; 60\% (sebanyak 18 responden dari total 30 responden). Keterlibatan mereka pada intensitas partisipasi "informasi", "konsultasi", "pengambilan keputusan" dan "prakarsa tindakan", ini mengindikasikan bahwa besar kemungkinan terjadi adanya perubahan di masyarakat yang dapat mendorong keberhasilan pelestarian Kebun dan Hutan Pendidikan STIPER.

Tabel 3. Keterlibatan Masyarakat Lokal pada Intensitas Partisipasi dalam Pelestarian Kebun dan Hutan Pendidikan STIPER

\begin{tabular}{c|l|c|c}
\hline \multirow{2}{*}{ No } & \multicolumn{1}{|c|}{ Keterlibatan Masyarakat } & \multicolumn{2}{c}{ Desa Karangan Hilir } \\
\cline { 3 - 4 } & & $\mathbf{N}$ & $\%$ \\
\hline 1. & Keikutsertaan dalam kegiatan Penyebaran Informasi & 12 & 40.00 \\
\hline 2. & Keikutsertaan dalam proses konsultasi & 3 & 10.00 \\
\hline 3. & Keikutsertaan dalam pengambilan keputusan & 2 & 3.33 \\
\hline 4. & Keikutsertaan dalam memprakarsai tindakan & - & 6.67 \\
\hline 5. & Keikutsertaan dalam pengawasan dan evaluasi & $\mathbf{1 8}$ & - \\
\hline & Jumlah responden berpartisipasi & $\mathbf{1 2}$ & $\mathbf{4 0}$ \\
\hline & Jumlah responden tidak berpartisipasi & $\mathbf{3 0}$ & $\mathbf{1 0 0}$ \\
\hline & T o t a I
\end{tabular}

Keterangan : $\mathrm{N}=$ jumlah responden

Tingkat Partisipasi Masyarakat Lokal dalam Pelestarian Kebun dan Hutan Pendidikan

\section{STIPER}

Partisipasi unsur masyarakat lokal dalam pelestarian Kebun dan Hutan Pendidikan STIPER, selanjutnya akan dijelaskann bentuk (apa dan bagaimana) dan tingkat partisipasi dari masing-masing unsur masyarakat lokal sebagai berikut :

Tingkat partisipasi pemimpin

Dalam penelitian ini unsur pemimpin terdiri dari 6 responden, yaitu: 1 Kepala Desa Karangan Hilir, 1 Sekretaris Desa Karangan Hilir, 2 Ketua RT, 1 tokoh masyarakat dan 1 Ketua Kelompok Tani. Tokoh masyarakat yang punya kharismatik di tengah masyarakat harus selalu dilibatkan dalam berbagai kegiatan pembangunan, sehingga setiap program pembangunan mendapat dukungan dari masyarakat. 
Secara keseluruhan unsur masyrakat lokal pemimpin yang berpartisipasi terdiri dari 4 responden $(66.66 \%)$ yang terlibat pada fungsi partisipasi "Perencanaan" dan "Pelaksanaan", sedangkan pada intensitas partisipasi terdapat 2 responden (33.33\%) terlibat pada "Prakarsa Tindakan", 1 responden (16.67\%) terlibat pada "Pengambilan Keputusan" dan 2 responden (33.33\%) terlibat dalam "konsultasi". Sehingga jika dituangkan dalam Tabel "participation Empowerment Index" sebagai berikut :

Tabel 4. Fungsi dan Intensitas Partisipasi Unsur Masyarakat Lokal Pemimpin dalam Pelestarian Kebun dan Hutan Pendidikan STIPER

\begin{tabular}{c|l|c|c|c|l|c|c}
\hline $\mathbf{I}$ & \multicolumn{1}{|c|}{$\begin{array}{c}\text { Fungsi } \\
\text { Partisipasi }\end{array}$} & $\mathbf{N}$ & $\%$ & $\mathbf{I}$ & \multicolumn{1}{|l}{ Intensitas Partisipasi } & $\mathbf{N}$ & $\%$ \\
\hline 5 & Manajemen & - & - & 5 & Pengendalian total & - & - \\
\hline 4 & Perencanaan & 2 & 33.33 & 4 & Prakarsa tindakan & 2 & 33.33 \\
\hline 3 & Pelaksanaan & 2 & 33.33 & 3 & Pengambilan keputusan & 1 & 16.67 \\
\hline 2 & Pemeliharaan & - & - & 2 & Konsultasi & 2 & 33.33 \\
\hline 1 & Distribusi & - & - & 1 & Informasi & - \\
\hline
\end{tabular}

Berdasarkan Tabel 4 di atas menunjukkan bahwa indeks partisipasi unsur masyarakat lokal kategori pemimpin berada pada angka 1, dalam fungsi partisipasi memiliki nilai yang sama pada "Perencanaan" dengan angka indeks $=4$, fungsi partisipasi "Pelaksanaan" pada angka indeks $=3$. Sementara intensitas partisipasi tertinggi pada "Prakarsa Tindakan" dengan angka indeks = 4 dan "konsultasi" dengan angka indeks $=2$. Sehingga dapat dihitung nilai tingkat partisipasi pemimpin dengan mengalikan angka indeks tesebut, yakni $1 \times 4 \times 4=16$. Dengan demikian partisipasi pemimpin dalam pelestarian Kebun dan Hutan Pendidikan STIPER masuk dalam kategori "sangat tidak aktif" (pada rentang nilai 1 - 25).

\section{Tingkat partisipasi kelompok minat}

Kelompok minat adalah unsur dari masyrakat lokal yang berpartisipasi secara aktif pada program pembangunan karena kelompok minat lazimnya dekat dengan program yang diminati. Sebagai suatu organisasi yang terbentuk dari masyarakat itu sendiri mestinya keberadannya dapat dijadikan penggerak bagi keberhasilan suatu program. Namun kenyataan di lapangan sering terjadi kelompok minat terbentuk secara tidak alami, tetapi lebih karena untuk persyaratan tertentu (Margiono, 1999).

Kelompok minat yang terlibat dalam pelestarian Kebun dan Hutan Pendidikan STIPER adalah dari anggota Kelompok Tani. Secara keseluran partisipasi unsur masyarakat lokal kelompok minat adalah sebanyak 4 responden $(66.66 \%)$ terlibat pada fungsi partisipasi "Pemeliharaan" dan "Distribusi" dan 5 responden (66.67\%) terlibat pada intensitas partisipasi "informasi" dan "Konsultasi". Sehingga jika dituangkan dalam tabel "participation Empowerment Index". Berdasarkan Tabel 5 menunjukkan bahwa indeks partisipasi unsur masyarakat lokal kategori kelompok minat berada pada angka indeks 2 , dalam fungsi partisipasi nilai sama pada "distribusi" dengan angka indeks = 1 dan pada 
"Pemeliharaan" dengan angka indeks $=2$. Sementara intensitas partisipasi tertinggi pada "informasi" dengan angka indeks $=1$. Sehingga dapat dihitung nilai tingkat partisipasi pemimpin dengan mengalikan 3 angka indeks tesebut, yakni $2 \times 2 \times 1=4$. Dengan demikian partisipasi kelompok minat dalam pelestarian Kebun dan Hutan Pendidikan STIPER masuk dalam kategori "sangat tidak aktif" (pada rentang nilai 1 - 25).

Tabel 5. Fungsi dan Intensitas Partisipasi Unsur Masyarakat Lokal Kelompok Minat dalam Pelestarian Kebun dan Hutan Pendidikan STIPER

\begin{tabular}{c|l|c|c|c|l|c|c}
\hline I & \multicolumn{1}{|c|}{$\begin{array}{c}\text { Fungsi } \\
\text { Partisipasi }\end{array}$} & N & $\%$ & I & Intensitas Partisipasi & N & $\%$ \\
\hline 5 & Manajemen & - & - & 5 & Pengendalian total & - & - \\
\hline 4 & Perencanaan & - & - & 4 & Prakarsa tindakan & - & - \\
\hline 3 & Pelaksanaan & - & - & 3 & Pengambilan keputusan & - & - \\
\hline 2 & Pemeliharaan & 2 & 33.33 & 2 & Konsultasi & 1 & 16.67 \\
\hline 1 & Distribusi & 2 & 33.33 & 1 & Informasi & 4 & 66.67 \\
\hline
\end{tabular}

Keterangan : $\mathrm{N}=$ jumlah responden $\mathrm{I}=$ Indeks

\section{Tingkat partisipasi kepala keluarga}

Kepala keluarga (kelompok rumah tangga) merupakan unsur masyarakat lokal yang dapat berkecimpung langsung dalam beberapa program pembangunan, partisipasi aktif dari keseluruhan kelompok rumah tangga dalam setiap program pembangunan merupakan prasyarat bagi keberhasilan suatu program. Karena keberadaannya sebagai pemimpin rumah tangga memungkinkan bagi kelompok ini untuk berperan lebih besar dalam berbagai kegiatan dan dalam berbagai hal mereka selalu dilibatkan (Margiono, 1999).

Tabel 6. Fungsi dan Intensitas Partisipasi Unsur Masyarakat Lokal Kepala Keluarga dalam Pelestarian Kebun dan Hutan Pendidikan STIPER

\begin{tabular}{c|l|c|c|c|l|c|c}
\hline I & Fungsi Partisipasi & N & $\%$ & I & Intensitas Partisipasi & N & $\%$ \\
\hline 5 & Manajemen & - & - & 5 & Pengendalian total & - & - \\
\hline 4 & Perencanaan & - & - & 4 & Prakarsa tindakan & - & - \\
\hline 3 & Pelaksanaan & - & - & 3 & Pengambilan keputusan & - & - \\
\hline 2 & Pemeliharaan & 2 & 33.33 & 2 & Konsultasi & - & - \\
\hline 1 & Distribusi & 3 & 50 & 1 & Informasi & 3 & 50 \\
\hline
\end{tabular}

Keterangan : $\mathrm{N}=$ jumlah responden $\mathrm{I}=$ Indeks

Secara keselurahan partisipasi unsur masyarakat lokal kepala keluarga pada pelestarian Kebun dan Hutan Pendidikan STIPER adalah sebanyak 5 responden (83.33\%) terlibat pada fungsi partisipasi "distribusi" dan "Pemeliharaan", sedangkan pada intensitas partisipasi sebanyak 3 responden (50\%) yang terlibat pada "informasi". Jika dituangkan dalam tabel "participation Empowerment Index" tercantum seperti Tabel 6. Berdasarkan Tabel 6 menunjukkan bahwa indeks partisipasi unsur masyarakat lokal kategori kepala keluarga berada pada angka indeks 3 , dalam fungsi partisipasi angka indeks tertinggi pada "distribusi" dengan angka indeks = 1 . Sedangkan intensitas partisipasi pada "informasi" dengan angka indeks $=1$. Sehingga dapat dihitung nilai tingkat partisipasi kepala keluarga dengan mengalikan 3 angka indeks tesebut, yakni $3 \times 1 \times 1=3$. Dengan demikian partisipasi kepala keluarga masuk dalam kategori "sangat tidak aktif" yakni berada pada rentang nilai 1 - 25 . 
Wanita merupakan salah satu unsur dalam masyarakat lokal yang jumlahnya banyak yang diharapkan dapat menjadi syarat bagi keberhasilan program pembangunan. Tetapi hal tersebut tidak terwujud dalam pelestarian Kebun dan Hutan Pendidikan STIPER. Hal tersebut dapat terlihat secara keseluruhan partisipasi unsur masyarakat lokal wanita pada pelestarian Kebun dan Hutan Pendidikan STIPER hanya sebanyak 2 responden (33.33\%), yang terlibat pada intensitas partisipasi "informasi". Sedangkan pada intensitas fungsi partisipasi tidak terdapat satupun masyarakat lokal wanita yang terlibat. Sehingga jika dituangkan dalam Tabel "participation Empowerment Index" sebagai berikut:

Tabel 7. Fungsi dan Intensitas Partisipasi Unsur Masyarakat Lokal Wanita dalam Pelestarian Kebun dan Hutan Pendidikan STIPER

\begin{tabular}{c|l|c|c|c|l|c|c}
\hline I & Fungsi Partisipasi & N & $\%$ & I & Intensitas Partisipasi & N & $\%$ \\
\hline 5 & Manajemen & - & - & 5 & Pengendalian total & - & - \\
\hline 4 & Perencanaan & - & - & 4 & Prakarsa tindakan & - & - \\
\hline 3 & Pelaksanaan & - & - & 3 & Pengambilan keputusan & - & - \\
\hline 2 & Pemeliharaan & - & - & 2 & Konsultasi & - & - \\
\hline 1 & Distribusi & - & - & 1 & Informasi & 2 & 33.33 \\
\hline
\end{tabular}

Berdasarkan Tabel 7 di atas menunjukkan bahwa indeks partisipasi unsur masyarakat lokal kategori wanita berada pada angka indeks 4 dalam intensitas partisipasi pada "informasi" dengan angka indeks = 1 , sedangkan fungsi partisipasi tidak ada satupun yang terlibat. Sehingga nilai tingkat partisipasi untuk wanita, yakni $4 \times 1=4$. Dengan demikian partisipasi wanita dalam pelestarian Kebun dan Hutan Pendidikan STIPER juga masuk dalam kategori "sangat tidak aktif" yakni berada pada rentang nilai 1 - 25 .

Tingkat partisipasi pemuda

Unsur pemuda yang aktif dalam partisipasi pelestarian Kebun dan Hutan Pendidikan STIPER terdiri dari; 6 responden $(66.66 \%)$ yang terlibat pada fungsi partisipasi "distribusi" dan "pemeliharaan", 3 responden (50\%) yang terlibat pada intensitas partisipasi "informasi". Jika dituangkan dalam tabel "participation Empowerment Index" sebagai berikut :

Tabel 8. Fungsi dan Intensitas Partisipasi Unsur Masyarakat Lokal Pemuda dalam Pelestarian Kebun dan Hutan Pendidikan STIPER

\begin{tabular}{c|l|c|c|c|l|c|c}
\hline I & Fungsi Partisipasi & N & $\%$ & I & Intensitas Partisipasi & N & $\%$ \\
\hline 5 & Manajemen & - & - & 5 & Pengendalian total & - & - \\
\hline 4 & Perencanaan & - & - & 4 & Prakarsa tindakan & - & - \\
\hline 3 & Pelaksanaan & - & - & 3 & Pengambilan keputusan & - & - \\
\hline 2 & Pemeliharaan & 2 & 33.33 & 2 & Konsultasi & - & - \\
\hline 1 & Distribusi & 2 & 33.33 & 1 & Informasi & 3 & 50 \\
\hline
\end{tabular}

Keterangan : $\mathrm{N}=$ jumlah responden, $\mathrm{I}=$ Indeks

Berdasarkan Tabel 8 menunjukkan bahwa indeks partisipasi unsur masyarakat lokal kategori pemuda berada pada angka indeks 5, dalam fungsi partisipasi angka indeks tertinggi pada "pemeliharaan" dengan angka indeks $=2$. Sedangkan intensitas partisipasi hanya satu partisipasi yaitu pada "informasi" dengan angka indeks $=1$. Sehingga dapat 
dihitung nilai tingkat partisipasi pemuda tersebut, yakni $5 \times 2 \times 1=10$. Dengan demikian partisipasi pemuda dalam pelestarian Kebun dan Hutan Pendidikan STIPER masuk dalam kategori "sangat tidak aktif" yakni berada pada rentang nilai 1-25.

Bentuk partisipasi dan tingkat partisipasi masyarakat lokal dalam pelestarian Kebun dan Hutan Pendidikan STIPER di atas diketahui bahwa tingkat partisipasi termasuk kategori "sangat tidak aktif", dengan demikian dapat dinyatakan bahwa tingkat partisipasi masyarakat lokal termasuk rendah yang akan berdampak pada ketidakberhasilan pelestarian Kebun dan Hutan Pendidikan STIPER. Menurut Margiono (1999), seluruh unsur masyarakat lokal seharusnya terlibat secara aktif dalam setiap proses pelaksanaan pembangunan karena tanpa keterlibatan (partisipasi) aktif masyarakat lokal keberhasilan dan keberlanjutan pembangunan sangat tidak mungkin dicapai bahkan tidak menutup kemungkinan akan menimbulkan permaslahan dan bahkan kegagalan bagi pembangunan itu sendiri.

Rendahnya partisipasi masyarakat lokal terhadap pelestarian Kebun dan Hutan Pendidikan STIPER disebabkan antara lain: (a) masyarakat dominan hanya terlibat pada fungsi "distribusi" dan "pemeliharaan", tidak terlibat pada fungsi manajeman, perencanaan dan pelaksanaan yang memungkinkan terakomodirnya aspirasi masyarakat lokal, (b) masyarakat hanya terlibat pada informasi dan konsultasi, tidak terlibat pada penganbilan keputusan, inisiatif tindakan dan pengendalian total, (c) Masyarakat yang tinggal di dalam dan/ di sekitar kawasan, menganggap pelestarian yang dilakukan akan mengganggu aktivitas mereka dan tidak akan meningkatkan kebutuhan hidupnya.

\section{Alternatif Upaya yang Dapat Dilaksanakan dalam Pelestarian Kebun dan Hutan Pendidikan STIPER}

Ditinjau dari masalah yang ada maka dalam mendukung program pelestarian Kebun dan Hutan Pendidikan STIPER harus berbasis partisipasi masyarakat lokal. Kebijakan pengelolaan ditujukan terutama untuk mengakomodasi kepentingan masyarakat, khususnya pemukim di sekitar kawasan, sehingga masyarakat harus dipandang sebagai bagian tak terpisahkan dari sistem pengelolaan kawasan.

Berbagai alternatif upaya pelestarian yang dapat dilaksanakan antara lain pada Tabel 9. Beberapa upaya pelestarian lainnya dapat dilakukan dengan mengadopsi konsep kelestarian yang dikemukakan oleh Maser (1994) bahwa upaya ideal yang dapat dilakukan guna mengelolah ekosistem (termasuk hutan di dalamnya) secara lestari sebagai berikut: menghasilkan barang dan jasa dan berbagai kondisi yang dibutuhkan oleh masyarakat, mencoba meningkatkan pautan antara kebutuhan masyarakat dan kemungkinan ekologis dimanapun dan kapanpun, memperbaiki ekosistem sejauh dimungkinkan guna mencapai 
ISSN 2354-7251 (print)

kapasitas yang produktif sehingga dapat menghasilkan berbagai barang, jasa dan kondisi yang dibutuhkan masyarakat.

Tabel 9. Alternatif Upaya yang Dapat Mendukung Keberhasilan Program Pelestarian Kebun dan Hutan Pendidikan STIPER

\begin{tabular}{c|l|l}
\hline No & $\begin{array}{c}\text { Kondisi Ke arah Positif } \\
\text { yang harus diciptakan }\end{array}$ & \multicolumn{1}{|c}{ Alternatif Upaya } \\
\hline $\mathbf{1}$ & \multicolumn{1}{|c}{$\mathbf{2}$} & \multicolumn{1}{c}{$\mathbf{1}$} \\
\hline \hline 1. & $\begin{array}{l}\text { Kombinasi perencanaan dari } \\
\text { atas dan dari bawah }\end{array}$ & $\begin{array}{l}\text { Membuat perencanaan program yang partisipatif dengan } \\
\text { melibatkan masyarakat lokal, Memberi prioritas terhadap } \\
\text { usulan masyarakat lokal }\end{array}$ \\
\hline 2. & Evaluasi multipihak & $\begin{array}{l}\text { Melibatkan masyarakat lokal dalam evaluasi hasil program, } \\
\text { Melibatkan instansi dari lembaga swadaya masyarakat terkait } \\
\text { dalam evaluasi program }\end{array}$ \\
\hline 3. & $\begin{array}{l}\text { Meningkatkan fungsi } \\
\text { partisipasi masyarakat lokal }\end{array}$ & $\begin{array}{l}\text { Melibatkan masyarakat lokal pada fungsi partisipasi } \\
\text { perencanaan dan Pelaksanaan dan jika memungkinkan pada } \\
\text { fungsi manajemen }\end{array}$ \\
\hline 5. & $\begin{array}{l}\text { Meningkatnya intensitas } \\
\text { partisipasi masyarakat lokal }\end{array}$ & $\begin{array}{l}\text { Melibatkan masyarakat lokal dalam pengambilan keputusan } \\
\text { yang terkait dengan program Kebun dan Hutan Pendidikan } \\
\text { STIPER }\end{array}$ \\
\hline 6. & Kosialisasi program intensif & $\begin{array}{l}\text { Meningkatkan frekuensi sosialisasi program, Setiap tahapan } \\
\text { program disosialisasikan dan Merancang kegiatan yang dapat } \\
\text { meningkatkan pendapatan masyarakat lokal }\end{array}$ \\
\hline
\end{tabular}

\section{$4 \quad$ Kesimpulan}

Partisipasi masyarakat lokal dalam pelestarian Kebun dan Hutan Pendidikan STIPER Kutai Timur masuk dalam kategori "sangat tidak aktif" atau berada pada rentang nilai 1-25 untuk 5 kelompok responden. Kategori partisipasi tersebut masih sangat rendah, hal ini disebabkan oleh pengelolaan Kebun dan Hutan Pendidikan STIPER secara keseluruhan masih ditangani secara langsung oleh STIPER dan masih kurang melibatkan masyarakat sekitar kawasan khususnya masyarakat desa Karangan Hilir. Dengan hasil yang masih sangat rendah maka diperlukan alternatif upaya meningkatkan peran serta masyarakat lokal dalam pelestarian kebun dan Hutan Pendidikan STIPER, dengan melibatkan masyarakat lokal dalam perencanaan, pelaksanaan, manajemen, pengambilan keputusan, melakukan inisiatif tindakan dan pengendalian program; meningkatkan frekuensi sosialisasi kepada masyarakat tentang keberadaan Kebun dan Hutan Pendidikan STIPER sebagai salah satu kawasan yang harus dijaga dan dilestarikan demi kualitas lingkungan yang lebih baik; melakukan penyuluhan yang dapat memberikan pemahaman pada masyarakat lokal tentang arti ekologi, arti ekonomi dan arti sosial dari keberadaan Kebun dan Hutan Pendidikan STIPER; dan, merancang kegiatan yang dapat dilakukan secara intensif yang mampu meningkatkan pendapatan masyarakat lokal. 


\section{Daftar Pustaka}

Arief, A. (1994). Hutan: Hakikat dan Pengaruhnya terhadap Lingkungan. Jakarta: Yayasan Obor Indonesia.

BKKBN. (2014). Kerjasama pendidikan kependudukan jalur non formal materi presentasi dari paper. Jakarta : Direktorat Kerjasama Pendidikan kependudukan.

Brown, K \& Pearce, D. (1994). The Cause of Tropical Deforestation. UCL Press. London

Cohen, L., Manion, L., \& Morrison, K. (2007). Research Methods in Education (6th ed.). London, New York: Routllege Falmer

Lestari, S.N.W. (2004). Analisis Tingkat Kepuasan Pengunjung dan Implikasinya Terhadap Taman Bunga Nusantara Cipanas, Kabupaten Cianjur. Skripsi. Fakultas Pertanian. Departemen IImu-IImu Sosial Ekonomi Pertanian, IPB. Bogor

Margiyono. (1999). Studi tentang Partisipasi masyarakat Lokal dalam Pembangunan Pedesaan. Program Pasca Sarjana Universitas Hasanuddin. Ujung Pandang

Maser, C. (1994). Sustainable Forestry Phylosophy, Science ang economic. St. Lucie Press. Debray Beach

Mubyarto. (1984). Strategi pembangunan Pedesaan. Yogyakarta: P3PK-Universitas Gajah Mada (UGM).

Pranoto, H. (2001). Analisis Kebijakan Pengelolaan sumber daya Hutan Dalam Rangka Penerepan Desentralisasi dan Peningkatan Partisipasi Masyarakat Lokal (Sebuah Studi di Kutai Kertanegara). Tesis. Program Pascasarjana Magister Program Studi IImu Kehutanan Universitas Mulawarman, Samarinda.

Purba, C., Nanggara, S. G., Ratriyono, M., Apriani, I., Rosalina, L., Sari, N.A. , \& Meridian, A. H. (2014). Potret Keadaan Hutan Indonesia Periode 2009-2013. Bogor: Forest Watch Indonesia.

Sembiring, S. N., Husbani, F., Arif, A. M., Ivalerina, F., \& Hanif, F. (1999). Kajian Hukum dan Kebijakan Pengelolaan Kawasan Konservasi di Indonesia: Menuju Pengembangan Desentralisasi dan Peningkatan Peranserta Masyarakat. Jakarta: ICEL.

Sugiyono (2012). Memahami Penelitian Kualitatif. Bandung: Alfabeta.

Sumantri, F. (2000). Pelatihan sumber daya dan Upaya Kemandirian Lembaga Bisnis Lokal dan Koperasi Kredit (LBL-KOPDIT) dalam Kawasan Pengembangan Ekonomi Terpadu (KAPET) Mbay Kabupaten Ngada, Propinsi Nusa Tenggara Timur. http://pasca.unhas.ac.id/jurnal_pdf/Vol_1_3/sumantri.

Sudjana. (1992). Metode Statistika. Bandung: Transito.

Sutrisno. (2004). Partisipasi Masyarakat dalam Konservasi Hutan Lindung Tarakan. Tesis. Pasca Sarjana Magister Program Studi Kehutanan Universitas Mulawarman. Samarinda 